$\xi=-1$

\title{
Determinants of Local Commercial Banks' Performance in Malaysia
}

\author{
Lee Wee Jeng ${ }^{1}$, Suganthi Ramasamy ${ }^{2 *}$, Devinaga Rasiah $^{3}$, Peter Yuen Yee Yen ${ }^{4}$, Shalini Devi Pillay ${ }^{5}$ \\ ${ }^{12,3,4,5}$ Faculty of Business, Multimedia University, Melaka, Malaysia. \\ *Corresponding author E-mail: suganthi.ramasamy@mmu.edu.my
}

\begin{abstract}
Commercial banks play an important role in developing a country's economy and maintaining its financial stability. Commercial banks will usually receive deposits from customers and lend out the money to people who need the money for their businesses or other legal purposes. Therefore, their performance is extremely important for a country's financial stability and economic growth. This research examined the determinants of local commercial banks' performance in Malaysia. Performance was measured using Return on Asset, Return on Equity and Net Interest Margin. Using data from eight local commercial banks in Malaysia from tea 2006 to year 2015 , this study found that credit risk, liquidity risk, bank's size and inflation rate significantly affect banks' performance.
\end{abstract}

Keywords: Commercial Bank; Financial Stability; Deposits, Lending; Economic Growth; Return On Asset; Return On Equity; Net Interest Margin; Credit Risk; Liquidity Risk; Bank Size And Inflation Rate

\section{Introduction}

Commercial banks act as an important character in the development of a country's economy and its financial system. Commercial banks usually receive deposits from people and lend out the money to those who need it for businesses or legal purposes. In the recent years, commercial banks have increased their product and services such as online banking, safe deposit boxes, credit card and more. Therefore, the performance of commercial banks is relevant and critical for the financial system of a country. The commercial banks must make sure that they are able to improve their service quality for customers, maintain financial stability as well as improve their performance leading towards an efficient financial system.

Furthermore, one of the ways that commercial banks earn profit is lending out loan and debt by charging interest rate for the loan borrower to repay the loan. Credit risk may arise from this service if the banks lack good credit management. Once the loan borrowers are unable to repay the loan or debt, the commercial banks will record it into doubtful debt or bad debt and this leads to losses. Therefore, it is also important for the banks to be aware and manage their credit risk to increase their performance in the banking sector.

There are lots of research had been done in overseas by other researches but there is less research had been conducted in Malaysia. Therefore, a research is needed to analyse the factors that might affect the performance of local commercial banks in Malaysia. In order to effectively manage the factors that affect bank performance, the commercial banks should understand the impact of these factors on the banks' performance. The main objective of this study to determine the factors that affect the local commercial banks' performance in Malaysia.

\section{Literature Review}

Since banks' performance had been a popular research topic, therefore there are many researches and studies had been done on determinants of banks' profitability over the world. Profit is the primary and important goal for commercial banks. Banks make money in several ways. The banks usually earn profit by lending out the money and receive the money they lend plus interest. However, the profitability level of the banks can be affected by several factors. According to Al-Tamimi \& Hussien (1) and Gul, Irshad, \& Zaman (2), the determinants of banks' performance or banks' profitability are assorted into external and internal factors. Internal factors are influenced by the bank size, capital, internal decisions of bank's management decisions, risk management capacity and the external factors are usually the macroeconomic factors which may affect banks operation like inflation rate.

The major financial ratios to measure profitability of commercial banks are measured by Return on Asset (ROA), Return on Equity (ROE) and Net Interest Margin (NIM). Return on Asset is a financial ratio that indicated the profitability of a bank. ROA measures the net income earned on assets of a bank or institution and how well the company uses its total assets to generate return. It give a meaning that how effectively the banks used the resources of the banks to generate income. ROA is measured by dividing the company's net income after tax by its total assets. Wu, Chen, \& Shiu (3) stated that ROA is an appropriate performance to measure bank performance because it captures the profit efficiency of banks. Since the purpose of assets are to generate profit, ROA enable the management team and investors evaluate how well the company can convert its investments in assets into profits. The most efficient banks are those banks that achieve highest levels of profits. Kumar \& Gulati (4), ROA is an overall performance including the non-interest return as well. 
ROE is also an important financial ratio in measuring bank performance. ROE measures how much profit of a bank can generated by using the total amount of shareholder equity. Molyneux \& Thornton (5) stated that ROE is a financial ratio used to identify a banks administration efficiently to use the shareholders' investment, most of the commercial banks use monetary control to maintain or increase their ROE to gain competitive advantage. The investors will look at the ROE to decide either they want to invest in the company or not. The higher the ROE, more investor will invest in the company which mean the better performance of the company. According to Berger \& De Young (6), ROE is the net profit after tax divide by the shareholder equity. This study also explored a group of US banks from 1983-1992 and measured the relationship between return on equity and capital adequacy ratio. This study also found out there is a significant link among both factors. The study by Ugur (7) stated that profitability and performance of financial institution are measured by return on equity ratio. This study also stated that ROE is useful for comparing the performance between companies in the same industry. The higher the ROE, the better the company in profit generation. In the study by Alexiou \& Sokoklis (8), ROA and ROE were used to measure the bank profitability level.

Net interest margin can be defined as the performance metric that examine how effective a bank's investment decisions when compared to its debt situations. NIM is helpful in tracking the bank's profitability from investing and lending activities over a period of time. The net interest margin also defined as the net yield on the interest-earning assets. This give a meaning of if a bank still can gain profit after pay all its debt and liability, the investment decisions of the bank is excellent and successful. The more successful of the bank, the higher the NIM, more customer or stakeholders will like to invest in the bank. Since net interest margin is the difference between interest income of the bank and the amount of interest paid out by the bank, thus, if the interest paid out by the bank higher than the interest income generated by the bank, net interest margin will be lower.

The study by Gul et al. (2) focused to determine the relationship between bank-specific and macroeconomic factors. This study had used the data of the top 15 Pakistan commercial banks over the period 2005-2009 to conduct the study. In the study, they have used the Pooled Ordinary Least Square (POLS) method to determine the impact of assets, equity, deposits, loans, inflation, economic growth and market capitalization on performance of the bank, measured through return on equity (ROE), return on asset (ROA), return on capital employed (ROCE) and net interest margin (NIM). By using these method, the results show that internal and external factors have significant impact on the performance of the banks.

\subsection{Credit Risk}

According to Basel (9), credit risk is the potential risk that a loan borrower fails to fulfil its obligations stated in the agreed terms. In other word, credit risk can be defined as the borrowers fail to repay in the loan they borrowed and causes the banks' performance decrease. The studies above also stated that credit risk have three characteristics which are exposure, borrower which default on its obligations and the recovery rate. If the bank fail to measure and manage the credit risk, it will definitely impact the performance of the banks.

Credit risk in the banking sector is measured by non-performing loans and non-performing asset which significantly influence the performance of the bank by Berger \& Deyoung (6) and Thiagarajan, Ayyapan, \& Ramachandran, (10). These study stated that if the non-performing asset of the banks increase, the higher the chance of credit default thus lower the bank profit. From the study of Berger and DeYoung (6), the bank may insolvency if the bank has too large proportions of non-performing loan. The study of Cooper, Jackson, \& Patterson (11)(2003) also stated that the dif- ferent level of credit risk may affect the performance of bank's loan which will significantly influence the bank performance.

Said \& Tumin (12) proved that credit risk will negatively affect the performance of the bank. In their studies, credit risk is negatively affected the return on asset and return on equity of the bank. In other word, it stated that the more the banks involved in loan with higher risk, the higher the chance of having non-performing loans in the banks which will turns the bank to earn lower return on the loan.

The research from Petria, Capraru, \& Ihnatov, 2015 (13) stated that credit risk is bank internal factor that will significantly impact on the bank profitability. The empirical finding of the study show that credit risk is negatively affect the return on asset (ROA) and return on equity (ROE). The study of Dietrich and Wanzenried (14 also provide that credit risk will lower down the performance of the bank. If the bank have higher credit risk, the performance of the bank is lower. Therefore, the study concluded that credit risk is negatively affect the performance of the bank.

However, the study by Flamini, Schumacher, \& McDonald (15) noted that there is a positive relationship of credit risk on the net interest margins of the banks as well as bank profitability. This research measured the ratio of deposits' loans and short- term funding to determine the credit risk of the bank. The result of the study found that credit risk has a positive relationship and significant influence on profitability of the bank.

\subsection{Liquidity Risk}

Liquidity is another factor that determines the bank performance. Liquidity is the ability of a financial institution to convert its liquid assets into cash to meet its short term obligation. Examples of liquid assets are central bank reserves, government debt, cash and etc. A financial institution like banks must have more liquid assets to fulfil its short-term obligation like withdrawals by their customer to avoid financial instability in the institution. Liquidity refers to how easy the financial institution can convert assets into cash. The most liquid asset is cash because cash can be used immediately to meet their short term obligation. The least liquid asset is usually real-estate like land, house, shop and etc. because the realestate take a longer time to sell.

Liquidity risk arise when the bank fail to convert the asset into cash to meet it short-term obligation. Banks generally need liquidity asset to maintain liquidity to meet the deposits from the customers. In other word, the study stated that liquidity risk arise when bank fail to provide needed funds for loan growth and deposit withdrawals from the customer. This can be proven by the study of Brunnermeier \& Pedersen (16), liquidity risk occurs when the bank are unable to convert their asset into cash in the market. The study also prove that liquidity risk also arise when the market is inefficient where it is difficult to gather the seller and buyer in the market. The failure of maintain liquidity in banks will lead to inefficiency in the banks.

According to Gul et.al (2), liquidity risk is calculated by total deposit divided by total asset. Bank with greater liquidity and less liquidity risk are likely to perform well when compare to lesser liquidity and higher liquidity risk. Bank with lower liquidity and higher liquidity risk are able to create less loans and the decrease of the loan will decrease the profit of the bank. The funds for loan growth are more likely derived from deposits, so it is expected that with lower deposit, profitability of the bank will be lower.

The study by Said \& Tumin (12) stated that there is no relationship between liquidity and the banks' performance. This study concluded that there is no significant influence of liquidity on bank profitability.

However, the study by Guru, Staunton, \& Balashanmugam (17) stated that liquidity risk is negatively affects the bank performance in terms of return on asset and return on equity by measuring the bank's financing gap ratio. The study of Sufian (18) by using current ratio to measure liquidity also provide that liquidity risk is negatively impact to bank profitability. Large banks with more 
loans will usually have larger financing gap ratio. The bank with higher financing gap ratio are usually unstable. Liquidity risk may arise when the bank has high funding cost and it will lower down the performance of the bank.

\subsection{Bank Size}

Many previous studies were conducted to determine the effect of bank's size on bank's performance. Many evidence in the empirical research confirmed that the bank's size is a factor that affecting the bank's performance. Different results have been found between the relationship of bank's size and bank's performance. Banks usually come in all sizes and shapes. Larger banks may can be greater efficiency, higher profitability and diversification. The factors that drive the bank to growth rapidly are diversification and economies of scale. However, if a bank grows too large in the market, it also may face the less efficiency, less profitability and higher risk.

According to Gul et al.(2) and Obamuyi (19), bank's size is calculated by the bank's total asset. The study of Gul et al. (2) also stated that bank's size is used to show the illusion that larger size banks might performing better than smaller banks in the economies of scale. Larger bank may have higher level of profit than smaller banks because of the economies of scale. They believe that there the bank's size might positively related to the bank profitability level.

In the study of Goddard, Molyneuz, \& Wilson (20), a positive relationship also been found between size of the bank and the profitability level of the bank. In these studies, total assets of the banks are used to measure the bank size. These studies also stated that larger bank will enjoy a higher level of profit and performance than the smaller banks because of the economies of scale.

The studies by Sufian (18), Flamini (15) and Gul et al.(2) also found that bank's size is positively affects the profitability of the banks. These study coming out with an idea that large banks can reduce cost and earn economies of scale and the larger bank are expected to have a higher amount of production than smaller banks. Larger banks are at a higher efficient level on average and more profitable than smaller banks because of the result of their efficiency and economies of scale. The larger bank earned higher earnings because they do not operate in a very competitive markets since their banks' size is larger than the smaller bank.

Dietrich \& Wanzenried (14) measured the level of income and total asset of the banks as bank's size on the determinants of bank performance. Their study concluded that negative relationship being found between bank's size and bank performance. Larger banks having huge losses and lower income due to several irrecoverable loans. Therefore, the size of the banks has different result in determine the performance of the bank. A further research has to conduct to determine the effect of bank size on bank's performance.

\subsection{Capital Adequacy}

Capital adequacy is one of an internal factor that might influence the performance of the commercial banks. According to Diamond \& Rajan (21), banks remain capital to protect unexpected financial distress occur. If a bank remains a certain amount of capital, it can create liquidity for the banks to overcome the problem of liquidity like deposit from the customer and etc. The bank can use its own funds to support and overcome the problem instead of borrowing from the others party or using another way to solve their financial problem. The researchers are using total equity to total assets ratio to measure the capital adequacy. The result show that there is a relationship between capital adequacy and performance of the banks.

The study by Pasiouras \& Kosmidou (22) proved that capital adequacy is significantly related to the performance of the banks. This statement can be proved by the study of Garcia-Herrero, Gavila, \& Santabarbara (23). From the study, the author use equity to asset ratio to measure the capital adequacy. From the result of the study, it shows that there is a relationship between capital adequacy and the performance of the bank. The amount of capital hold by the banks can impact the performance of the banks.

The study of Al-Tamimi\& Hussien (1) identified one of the most important variable in affecting the profitability of the banks is capital adequacy. The study carried a result that capital adequacy is significant and positively related to profitability of the banks. In the study, the capital adequacy is affecting the return on assets on the banks. It provided that higher capital adequacy of a bank, the higher the profitability of the bank.

However, the study of Hoffmann (24) showed that capital adequacy is significant but negatively related to performance of the banks. The result of the study shows that banks with higher capital adequacy ratio will have lower performance. The study proved that if the bank maintains or increase too much of capital, the performance of the bank will decrease. An unexpected huge increase in the capital adequacy may lead to banks insufficient to manage the capital and therefore the performance of the banks decrease.

The study of Al-Tamimi \& Obeidat (25) carry out in Jordan for the period 2000 to 2008 to find out the important of capital adequacy in bank performance. The researchers used multiple linear regression method to analyse the data result. However, the result showed that capital adequacy is significant but negative related to return on equity. It provided that if a bank holds higher capital adequacy, the lower the bank performance.

\subsection{Inflation Rate}

Inflation is also an important factor in the macroeconomic. Inflation reflects a reduction of citizen as well as consumer in the purchasing power in a country. In other word, each unit of currency purchase fewer food and services when there is an inflation. The inflation rate is calculated by using consumer price index.

According to Guru et al. (17), one of the most important macroeconomic factors that measured the bank performance is inflation. In the result of the study, inflation is proved to have a positive relationship with bank performance. Pasiouras \& Kosmidou (22) stated that inflation rate is an important macroeconomic factor that used to measure the bank's performance by measuring the return on average assets (ROAA). The study concluded that the inflation rate has impact on the ROAA. Similarly, the study of GarciaHerrero et al. (2009) also provided the same result that an increase in inflation rate will definitely increase the bank's return on asset (ROA).

The study of Alexiou \& Sofoklis (8) stated that inflation is measured as CPI and CPI has a positive influence on return on asset (ROA). The finding suggests that if the domestic commercial banks can have predicted the inflation correctly, they are able to adjust the interest rate and earn more profits during inflation. The result can be proved by the study of Sufian (18) which identify the determinants of bank profitability. In measuring the inflation, the result show that positive relationship has been found between inflation and bank performance.

The research carried out by Gul et al. (2) used inflation rate as one of the macroeconomic factors to identify the performance of the banks. Top fifteen banks' data in South Asian countries have been chosen to be used to measure in the research. The result of the research stated that inflation rate has positively relationship with bank's performance.

Besides, Kanas, Vasiliou, \& Eriotis (26) also using inflation rate to determine the bank's performance. The result concluded that inflation rate has a significant impact on the bank's return on asset (ROA) and return on equity (ROE). This study noted that there is a positive relationship between inflation rate and bank's profitability level.

On the other hand, research by Anbar \& Alper (27) also used inflation rate as one of the external factor to measure bank's performance. Consumer Price Index (CPI) is being measured in the research to identify the inflation rate in the country because the in- 
flation rate in the particular country will affect the real costs and revenues. However, they found that inflation rate has no important influence on the bank's profitability. The study from Petria et al. (13) also concluded that inflation rate has no influence the performance of the banks.

\section{Research Methodology}

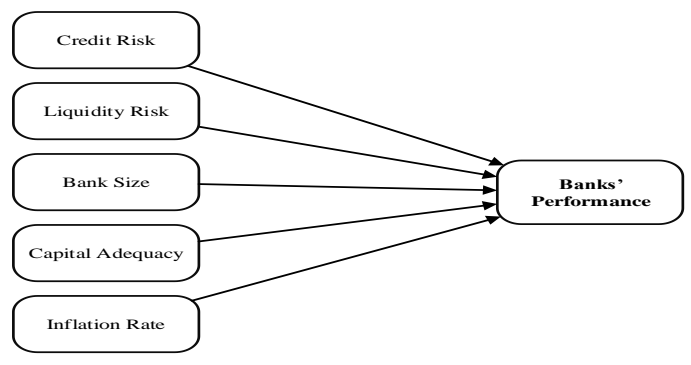

Fig. 1: Theoretical Framework

Figure 1 shows the theoretical framework of this study. The dependent variable in this study is banks' performance. Banks' performance is measured by Return on Asset (ROA), Return on Equity (ROE), Net Interest Margin (NIM). ROA is used to measure how efficiency a bank can generate revenue by using its total assets. ROE is an indicator to measure how efficiency a bank can generate return with the money from shareholders' equity while NIM is the difference between the interest income generated by the bank and the interest paid out by the banks. ROA, ROE and NIM are widely used indicator in comparing the performance of a business especially in banking sector. ROA is measured by profit after tax divided by total asset. ROE is measured by net profit after tax divided by shareholders' equity. NIM is measured by interest income minus interest expenses and divided by average earning assets.

The first independent variable is credit risk. Credit risk arise when borrowers are unable to make repayment on loan. Several ways cab be used to measure credit risk such as risk weighted assets, non-performing loan and etc. Provision for loan loss is used in this study to measure credit risk. Higher loan loss provision will reduce the performance of the banks. The lower the ratio, the better for the banks. The second independent variable is liquidity risk. Liquidity risk arise when a bank is unable to meet it short term obligations. In other words, liquidity risk arises when a bank has no sufficient cash and liquidity assets to meet the customer withdrawals, loan demand and other cash needs by the customer. It also arises when the bank has too much of illiquidity assets which are not easily can be convert to cash in the market. Current ratio is selected to measure liquidity risk in this study. Current ratio is being widely used ratio in measuring the liquidity of a bank. The higher the ratio, the more liquidity of the bank.

The next independent variable is bank size. Bank size is calculated by ordinary logarithm to total assets of the bank. Larger banks tend to be more profitability than smaller banks due to the economics of scales. However, larger banks may face the liquidity problems and diversifying in risk. The fourth independent variable is capital adequacy. Capital adequacy is the amount of funds maintain and managed by the banks to overcome financial distress or to support the operating business of the banks. Capital adequa- cy ratio show how well the bank's internal strength is to maintain stability during financial crisis. Capital adequacy is the ratio of total equity to total assets of the banks.

Last variable is Inflation rate which refer to percentage changes in prices of goods and services and it is calculated in yearly basis. Inflation rate can also use to measure how quick a country currency value appreciates or depreciates. Inflation rate is important for the banks because banks might invest in long term investment, the higher the inflation, the lower the value of the investment, the return will be lower than the banks expected.

The hypothesis tested are as follows:

H1a: Credit risk significant affect bank performance.

H1a: Liquidity risk significant affect bank performance.

H1c: Bank's size significant affect bank performance.

H1d: Capital adequacy significant affect bank performance.

H1e: Inflation rate significant affect bank performance.

The data of this study is chosen from the annual report of eight local commercial banks in Malaysia which are Affin Bank Berhad, Alliance Bank Malaysia Berhad, AmBank (M) Berhad, CIMB Bank Berhad, Hong Leong Bank Berhad, Malayan Banking Berhad, Public Bank Berhad and RHB Bank Berhad. The period covered in this study from year 2006 to 2015 .

\section{Findings}

Table 2, shows the descriptive statistics for the dependent and independent variables. ROA of the eight local commercial banks has a mean of $1.04 \%$. The mean value ROE and NIM are $12.60 \%$. and $1.90 \%$ respectively. During the period between 2006 to 2015 , highest credit risk recorded was $4.42 \%$, while the highest liquidity risk was 117.00.

Table 3 shows the multicollinearity result of the independent variable.

Since all the correlation values are below 0.7 , therefore none of the independent variables are highly correlated to each other.

Table 4, Table 5 and Table 6 shows the result of the pooled least square analysis on ROA, ROE and NIM respectively.

Based on Table 4, all the independent variables have significant relationship to ROA except for capital adequacy. Table 5 shows that all the independent variables have significant relationship to ROE. Table 6 shows that only inflation rate is significantly related to NIM.

Table 7: Table 8 and Table 9 shows the result of the fixed effect analysis on ROA, ROE and NIM respectively.

Table 7 shows the credit risk and liquidity risk are significantly negatively related to ROA. This shows that the higher the credit risk and liquidity risk of the Malaysia commercial banks, the lower the ROA will be. Meanwhile, capital adequacy is significantly positively related to ROA indicating that the higher the capital adequacy of the banks, higher will be the bank performance.

As shown in Table 8, both credit risk and liquidity risk are significantly negatively related to ROE. This shows that banks with higher credit risk and liquidity risk would have lower ROE. Similar result was also found by Petria et al. (13).

Based on Table 9, only capital adequacy is significantly positively related to NIM indicating that banks that hold more capital generally have higher NIM. Similar result was also found by GarciaHerrero et al. (23).

Table 2: Descriptive Statistics of the variables

\begin{tabular}{|c|c|c|c|c|}
\hline Variable & Mean & Minimum & Maximum & Std. Dev. \\
\hline Return on Asset (\%) & 1.04 & -0.86 & 1.91 & 0.38 \\
\hline Return on Equity (\%) & 12.60 & -11.58 & 28.18 & 5.51 \\
\hline Net Interest Margin (\%) & 1.90 & 0.96 & 2.66 & 0.31 \\
\hline Liquidity Risk (\%) & 110.56 & 105.00 & 117.00 & 2.55 \\
\hline Bank Size (RM) & $179,062,000,000$ & $23,581,200,000$ & $708,345,000,000$ & $147,225,000,000$ \\
\hline Capital Adequacy (\%) & 8.57 & 5.13 & 12.35 & 1.63 \\
\hline
\end{tabular}


Table 3: Multicollinearity for all the independent variables.

\begin{tabular}{|c|c|c|c|c|l|}
\hline Credit Risk & Liquidity Risk & Bank Size & Capital Adequacy & Inflation Rate & \\
\hline 1.0000 & -0.0898 & -0.3012 & -0.1686 & -0.5884 & Credit Risk \\
\hline & 1.0000 & 0.1461 & 0.5616 & 0.2802 & Liquidity Risk \\
\hline & & 1.0000 & -0.2804 & 0.3486 & Bank Size \\
\hline & & & 1.0000 & 0.3668 & Capital Adequacy \\
\hline & & & & 1.0000 & Inflation Rate \\
\hline
\end{tabular}

Table 4: Pooled OLS analysis for ROA and independent variables 80 observations, Included 8 cross-sectional units, Time-series length $=10$ Dependent variable: Return on Asset

\begin{tabular}{|c|c|c|c|c|c|}
\hline \multicolumn{6}{|c|}{$\begin{array}{c}80 \text { observations, Included } 8 \text { cross-sectional units, Time-series length }=10 \\
\text { Dependent variable: Return on Asset } \\
\text { Robust (HAC) standard errors }\end{array}$} \\
\hline & Coefficient & Std. Error & t-ratio & $p$-value & \\
\hline Const & 0.0331 & 0.0202 & 1.6429 & 0.1444 & \\
\hline Credit Risk & -0.4405 & 0.0352 & -12.5074 & $<0.0001$ & **** \\
\hline Liquidity Risk & -0.0420 & 0.0180 & -2.3303 & 0.0526 & * \\
\hline Bank Size & 0.0014 & 0.0006 & 2.3572 & 0.0506 & * \\
\hline Capital Adequacy & 0.0509 & 0.0400 & 1.2742 & 0.2433 & \\
\hline Inflation Rate & -0.0001 & $6.83248 \mathrm{e}-05$ & -2.0243 & 0.0826 & * \\
\hline R-squared & \multicolumn{3}{|c|}{\begin{tabular}{|l|l|}
0.6389 & P-value $(\mathrm{F})$ \\
\end{tabular}} & & $2.90 \mathrm{e}-06$ \\
\hline $\mathrm{F}(5,7)$ & \multicolumn{3}{|c|}{\begin{tabular}{l|l|}
94.1926 & Durbin-Watson \\
\end{tabular}} & & 1.2015 \\
\hline
\end{tabular}

Note: * significant at $10 \%$; ** significant at $5 \%$;*** significant at $1 \%$

Table 5: Pooled OLS analysis for ROE and independent variables

80 observations, Included 8 cross-sectional units, Time-series length $=10$

Dependent variable: Return on Equity

Robust (HAC) standard errors

\begin{tabular}{|c|c|c|c|c|c|}
\hline & Coefficient & Std. Error & t-ratio & p-value & \\
\hline Const & 0.6629 & 0.2883 & 2.2994 & 0.0550 & $*$ \\
\hline Credit Risk & -6.1190 & 0.5086 & -12.0302 & $<0.0001$ & $* * *$ \\
\hline Liquidity Risk & -0.5975 & 0.2646 & -2.2582 & 0.0585 & $*$ \\
\hline Bank Size & 0.0170 & 0.0069 & 2.4758 & 0.0425 & *** \\
\hline Capital Adequacy & -0.8198 & 0.3343 & -2.4524 & 0.0440 & $* *$ \\
\hline \begin{tabular}{|l|} 
Inflation Rate \\
\end{tabular} & -0.0020 & 0.0006 & -3.2304 & 0.0144 & ** \\
\hline R-squared & \multicolumn{3}{|c|}{\begin{tabular}{|l|l|l}
0.7394 & $\mathrm{P}$-value $(\mathrm{F})$ \\
\end{tabular}} & & 0.000023 \\
\hline
\end{tabular}

Note: $*$ significant at $10 \%$; ** significant at $5 \%$; *** significant at $1 \%$

Table 6: Pooled OLS analysis for NIM and independent variables.

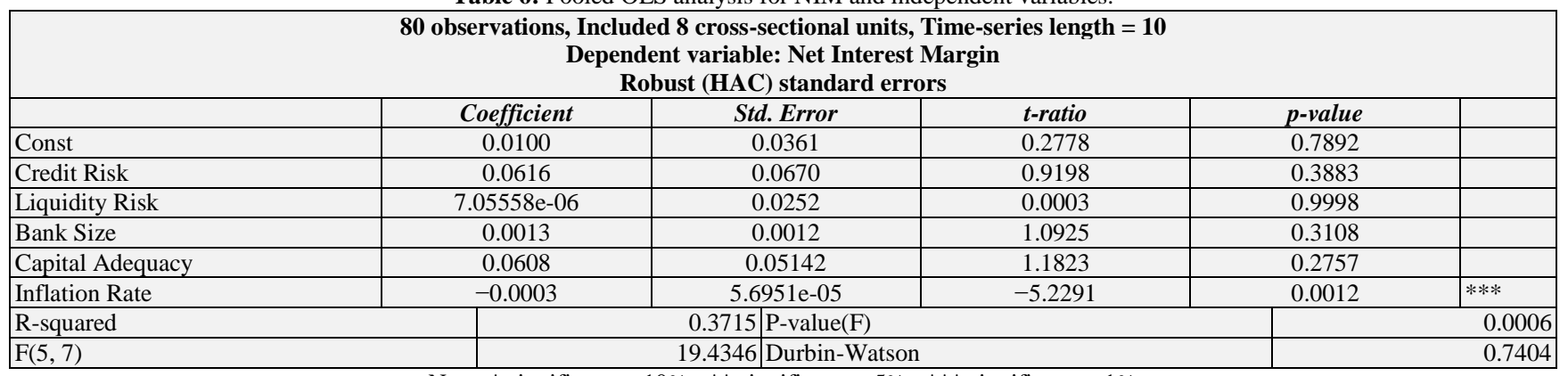

Note: * significant at $10 \%$; ** significant at $5 \%$; *** significant at $1 \%$

Table 7: Fixed-effects for ROA and independent variables

80 observations, Included 8 cross-sectional units, Time-series length $=10$

Dependent variable: Return on Asset

Robust (HAC) standard errors

\begin{tabular}{|c|c|c|c|c|c|}
\hline & Coefficient & Std. Error & t-ratio & p-value & \\
\hline Const & 0.1012 & 0.0516 & 1.9611 & 0.0907 & $*$ \\
\hline Credit Risk & -0.4630 & 0.0175 & -26.5184 & $<0.0001$ & $* * *$ \\
\hline Liquidity Risk & -0.0469 & 0.0120 & -3.9158 & 0.0058 & **** \\
\hline Bank Size & -0.0015 & 0.0018 & -0.8224 & 0.4380 & \\
\hline Capital Adequacy & 0.1180 & 0.0355 & 3.3246 & 0.0127 & $* *$ \\
\hline Inflation Rate & $-7.86838 \mathrm{e}-05$ & $9.65667 \mathrm{e}-05$ & -0.8148 & 0.4420 & \\
\hline
\end{tabular}

\begin{tabular}{|l|c|c|c|c|}
\hline LSDV R-squared & 0.8064 & Durbin-Watson & 1.9506 \\
\hline
\end{tabular}

Joint test on named regressors -

Test statistic: $\mathrm{F}(5,7)=708.894$

with $\mathrm{p}$-value $=\mathrm{P}(\mathrm{F}(5,7)>708.894)=2.63219 \mathrm{e}-009$

Robust test for differing group intercepts -

Null hypothesis: The groups have a common intercept

Test statistic: Welch F(7, 30.7) = 7.97247 
with p-value $=\mathrm{P}(\mathrm{F}(7,30.7)>7.97247)=1.62944 \mathrm{e}-005$

Note: * significant at $10 \% ; * *$ significant at $5 \%$; *** significant at $1 \%$

Table 8: Fixed-effects for ROE and independent variables

80 observations, Included 8 cross-sectional units, Time-series length $=10$

Dependent variable: Return on Equity

Robust (HAC) standard errors

\begin{tabular}{|c|c|c|c|c|c|}
\hline & Coefficient & Std. Error & t-ratio & p-value & \\
\hline Const & 1.6033 & 0.6623 & 2.4208 & 0.0460 & ** \\
\hline Credit Risk & -6.1435 & 0.2023 & -30.3636 & $<0.0001$ & *** \\
\hline Liquidity Risk & -0.4119 & 0.1340 & -3.0754 & 0.0179 & ** \\
\hline Bank Size & -0.0360 & 0.0254 & -1.4155 & 0.1998 & \\
\hline Capital Adequacy & -0.4122 & 0.5349 & -0.7706 & 0.4662 & \\
\hline Inflation Rate & -0.0003 & 0.0014 & -0.2299 & 0.8248 & \\
\hline LSDV R-squared & 0.8651 & & Durbin-Watson & 2.07 & \\
\hline
\end{tabular}

Joint test on named regressors -

Test statistic: $\mathrm{F}(5,7)=358.316$

with p-value $=\mathrm{P}(\mathrm{F}(5,7)>358.316)=2.84129 \mathrm{e}-008$

Robust test for differing group intercepts -

Null hypothesis: The groups have a common intercept

Test statistic: Welch $\mathrm{F}(7,30.6)=8.74771$

with p-value $=\mathrm{P}(\mathrm{F}(7,30.6)>8.74771)=6.99696 \mathrm{e}-006$

Note: * significant at $10 \% ; * *$ significant at $5 \%$; *** significant at $1 \%$

Table 9: Fixed-effects for NIM and independent variables

80 observations, Included 8 cross-sectional units, Time-series length $=\mathbf{1 0}$

Dependent variable: Net Interest Margin

Robust (HAC) standard errors

\begin{tabular}{|c|c|c|c|c|c|}
\hline & Coefficient & Std. Error & t-ratio & p-value & \\
\hline Const & 0.1120 & 0.0827 & 1.3541 & 0.2178 & \\
\hline Credit Risk & 0.0124 & 0.0348 & 0.3562 & 0.7322 & \\
\hline Liquidity Risk & -0.0080 & 0.0143 & -0.5569 & 0.5949 & \\
\hline Bank Size & -0.0030 & 0.0036 & -0.8141 & 0.4424 & \\
\hline Capital Adequacy & 0.0873 & 0.0242 & 3.6116 & 0.0086 & *** \\
\hline Inflation Rate & -0.0002 & 0.0002 & -1.0096 & 0.3463 & \\
\hline LSDV R-squared & 0.7380 & & Durbin-Watson & & \\
\hline
\end{tabular}

Joint test on named regressors -

Test statistic: $\mathrm{F}(5,7)=36.357$

with $\mathrm{p}$-value $=\mathrm{P}(\mathrm{F}(5,7)>36.357)=7.29127 \mathrm{e}-005$

Robust test for differing group intercepts -

Null hypothesis: The groups have a common intercept

Test statistic: Welch $\mathrm{F}(7,30.7)=17.286$

with p-value $=\mathrm{P}(\mathrm{F}(7,30.7)>17.286)=4.79198 \mathrm{e}-009$

Note: $*$ significant at $10 \%$; ** significant at $5 \% ; * * *$ significant at $1 \%$.

\section{Conclusion}

Credit risk is found to be significant and negatively related to the ROA and ROE of the local commercial banks in Malaysia. This show that the higher the loan loss provision or credit risk in the local commercial banks, the lower the ROA and ROE of the local commercial banks. This result is consistent with the research of Dietrich \& Wanzenried (14). The past researchers also claim that there is negative relationship between the credit risk and the performance of the banks. The banks will have to increase the amount of provision for loan loss when exposed to higher credit risk.

Besides that, this research also reveals that liquidity risk is significant and negatively related to the ROA and ROE of the local commercial banks. It proved that the higher the liquidity risk, the local commercial banks will have lower performance. Similar result can be found in the research of Petria et al. (13). The past researchers also provided that liquidity risk is negatively impact on the bank performance. This showed that if the local commercial banks have more liquidity risk, the performance will be lower. Capital adequacy was found to be significantly and positively related to the ROA and NIM of the local commercial banks. This provide that if a local commercial bank holds more capital adequacy, the performance of the bank will be higher. Similar result has been found in the research of San \& Heng (28) in Malaysia. The past researchers also claimed that the capital adequacy of the bank is positively related to the performance of the banks.
However, bank size and inflation are not significantly related to banks' performance. The negative association between bank size and bank performance reveals that if the local commercial banks expand their business, the performance of the local commercial banks will be lower. Based on the study of Stiroh \& Rumble (29), the researchers have proved that there is adverse relationship being found among bank size and the banks' performance.

This research is important to the local commercial banks because it provide useful information to the local commercial banks. Management team of the local commercial banks should take action in managing the credit risk. The commercial banks should reduce high risk loan to avoid loan loss provision from their customers. The banks performance will be higher when the credit risk is lower in the banks. Since liquidity risk is also negatively related to the local commercial banks' performance, the local commercial banks should also avoid liquidity risk occur in the banks. The management team of the banks should effectively measure the liquidity risk of the banks to avoid the performance of the banks to become worse. With the effective management of credit risk and liquidity risk, the banks can easily achieve their goal in the future. Negative relationship is found between bank's size and performance of the local commercial banks. Therefore, the local commercial banks can reduce the expansion of their business and have more subsidiaries in Malaysia. It is difficult for the local commercial banks to manage too much of the subsidiaries and lead to the performance of the banks to be lower. The local commercial banks can also increase their capital adequacy in the banks since capital 
adequacy is positively related to the performance of the local commercial banks. Higher capital adequacy will allow the local commercial banks to easily overcome the financial distress if any distress occur. The customer will gain more confidence in the well-capitalized banks, they will start deposits and borrow loan from the banks and this will lead to higher performance of the banks.

\section{References}

[1] Al-Tamimi H, Hussein A. Factors influencing performance of the UAE Islamic and conventional national banks. 2010.

[2] Gul S, Irshad F, Zaman K. Factors Affecting Bank Profitability in Pakistan. Romanian Economic Journal. 2011;14(39).

[3] Wu H-L, Chen C-H, Shiu F-Y. The impact of financial development and bank characteristics on the operational performance of commercial banks in the Chinese transitional economy. Journal of Economic Studies. 2007;34(5):401-14.

[4] Kumar S, Gulati R. Measuring efficiency, effectiveness and performance of Indian public sector banks. International Journal of Productivity and Performance Management. 2009;59(1):51-74.

[5] Molyneux P, Thornton J. Determinants of European bank profitability: A note. Journal of banking \& Finance. 1992;16(6):1173-8.

[6] Berger AN, DeYoung R. Problem loans and cost efficiency in commercial banks. Journal of Banking \& Finance. 1997;21(6):84970.

[7] Ugur Z. Commercial banks and microfinance. CUREJ-College Undergraduate Research Electronic Journal. 2006:35.

[8] Alexiou C, Sofoklis V. Determinants of bank profitability: Evidence from the Greek banking sector. Economic annals. 2009;54(182):93-118.

[9] Supervision BCoB, Settlements BfI. Principles for the management of credit risk: Bank for International Settlements; 2000

[10] Thiagarajan S, Ayyappan S, Ramachandran A. Credit risk determinants of public and private sector banks in India. European Journal of Economics, Finance and Administrative Sciences. 2011;34:147-54.

[11] Cooper MJ, Jackson WE, Patterson GA. Evidence of predictability in the cross-section of bank stock returns. Journal of Banking \& Finance. 2003;27(5):817-50.

[12] Said RM, Tumin MH. Performance and financial ratios of commercial banks in Malaysia and China. International Review of Business Research Papers. 2011;7(2):157-69.

[13] Petria N, Capraru B, Ihnatov I. Determinants of banks' profitability: evidence from EU 27 banking systems. Procedia Economics and Finance. 2015;20:518-24.

[14] Dietrich A, Wanzenried G. The determinants of commercial banking profitability in low-, middle-, and high-income countries. The Quarterly Review of Economics and Finance. 2014;54(3):33754.

[15] Flamini V, Schumacher ML, McDonald MCA. The determinants of commercial bank profitability in Sub-Saharan Africa: International Monetary Fund; 2009.

[16] Brunnermeier MK, Pedersen LH. Market liquidity and funding liquidity. The review of financial studies. 2008;22(6):2201-38.

[17] Guru BK, Staunton J, Balashanmugam B. Determinants of commercial bank profitability in Malaysia. Journal of Money, Credit, and Banking. 2002;17:69-82.

[18] Sufian F. Determinants of bank profitability in a developing economy: empirical evidence from the China banking sector. Journal of Asia-Pacific Business. 2009;10(4):281-307.

[19] Obamuyi TM. Determinants of banks' profitability in a developing economy: Evidence from Nigeria. Organizations and markets in emerging economies. 2013;4(2):97-111.

[20] Goddard JA, Molyneux P, Wilson JO. Dynamics of growth and profitability in banking. Journal of Money, Credit, and Banking. 2004;36(6):1069-90.

[21] Diamond DW, Rajan RG. A theory of bank capital. The Journal of Finance. 2000;55(6):2431-65.

[22] Pasiouras F, Kosmidou K. Factors influencing the profitability of domestic and foreign commercial banks in the European Union. Research in International Business and Finance. 2007;21(2):222-37.

[23] García-Herrero A, Gavilá S, Santabárbara D. What explains the low profitability of Chinese banks? Journal of Banking \& Finance. 2009;33(11):2080-92.
[24] Hoffmann PS. Determinants of the Profitability of the US Banking Industry. International Journal of Business and Social Science. $2011 ; 2(22)$.

[25] Moh'd Al-Tamimi KA, Obeidat SF. Determinants of capital adequacy in commercial banks of Jordan an empirical study. International Journal of Academic research in Economics and management sciences. 2013;2(4):44.

[26] Kanas A, Vasiliou D, Eriotis N. Revisiting bank profitability: A semi-parametric approach. Journal of International Financial Markets, Institutions and Money. 2012;22(4):990-1005.

[27] Anbar A, Alper D. Bank specific and macroeconomic determinants of commercial bank profitability: Empirical evidence from Turkey. 2011.

[28] San OT, Heng TB. Factors affecting the profitability of Malaysian commercial banks. African Journal of Business Management. 2013;7(8):649-60.

[29] Stiroh KJ, Rumble A. The dark side of diversification: The case of US financial holding companies. Journal of banking \& finance. 2006;30(8):2131-61. 